\title{
How the quality of patents contributes to revitalising the innovation system?, evidence from the renewable energy sector
}

\author{
¿Cómo la calidad de las patentes contribuye a revitalizar el sistema \\ de innovación?, Evidencia desde el sector de energías renovables
}

Milton Mauricio Herrera-Ramírez ${ }^{1}$
Edgard Alberto Méndez-Morales ${ }^{2}$
Diana Marlene Barrios-Campos

Recibido: mayo 05 de 2020 Aceptado: noviembre 30 de 2020

\begin{abstract}
There is an intense discussion on the impact of the quality of patents on innovation and economic development. Consequently, measuring the quality of patents becomes an essential issue to understand how it affects the innovation system (IS). This paper shows a systematic review of patent quality indicators and their contribution to the literature. Additional to the systematic review, a dynamic behaviour hypothesis is developed to comprise how patent value indicators can be used to create a set of strategies to improve the innovation of the renewable energy sector. Our results show a novel framework for analysing the effects of patent value on the IS that could be useful for renewable energy diffusion in Latin-America.
\end{abstract}

Keywords: technological innovation system, patent analysis, renewable energy, systemic intervention.

\begin{abstract}
Resumen
Existe una intensa discusión sobre el impacto de la calidad de las patentes en la innovación y el desarrollo económico. En consecuencia, la medición de la calidad de las patentes se convierte en un tema esencial para comprender como afecta el sistema de innovación (SI). Este artículo muestra una revisión sistemática de los indicadores de calidad de las patentes y su contribución a la literatura. Además de la revisión sistemática, se elabora una hipótesis de comportamiento dinámico para comprender cómo los indicadores de valor de las patentes, se pueden utilizar para crear un conjunto de estrategias para mejorar la innovación del sector de las energías renovables. Los resultados muestran un marco novedoso para analizar los efectos del valor de las patentes en el SI, que podría ser útil para la difusión de la energía renovable en América Latina.
\end{abstract}

Palabras clave: sistema de innovación tecnológico, análisis de patentes, energía renovable, intervención sistémica.

1 Production Engineering, PhD. in Model Based Public Planning, Policy Design and Management, Universidad Militar Nueva Granada, Bogotá, Colombia. E-mail: milton.herrera@unimilitar.edu.co

ORCID: https://orcid.org/0000-0002-0766-8391

2 Economist, PhD. in Economics and Innovation Management, Universidad Militar Nueva Granada, Bogotá, Colombia. E-mail: edgard. mendez@unimilitar.edu.co

ORCID: https://orcid.org/0000-0001-7971-5305

3 Economist, MSc in Economics, Universidad Militar Nueva Granada, Bogotá, Colombia. E-mail: dianabarriosc@gmail.com ORCID: https://orcid.org/0000-0002-6316-2627 
¿Cómo la calidad de las patentes contribuye a revitalizar el sistema de innovación?, Evidencia desde el sector de energías renovables

\section{Introduction}

In the last decade, several countries have increased the number of patent applications as a consequence of subsidies and investment aimed to improve the innovation activities, particularly in renewable energy technologies (Lu, 2013; Miyamoto \& Takeuchi, 2019; Romano et al., 2017). Patents include information that can be used as an indicator to assess the technological development of a country (Boeing \& Mueller, 2016; Ernst, 2003). Thus, patents become a significant source of information to understand the dynamics of the Innovation System (IS).

Researchers and policymakers have shown keen interest in patent analysis (Abbas et al., 2014; Squicciarini et al., 2013; Tseng et al., 2007). In this sense, the patent information systems provide several measures that have been used as quality indicators for patent analysis (Boeing \& Mueller, 2019). However, the patent information sources, especially in Latin America, are scarce, and that makes the study of these topics in the region complex and critical (Barroso et al., 2009). Additionally, patent analysis comprises several dimensions, which determine the features of a patent that make it "good" or "bad", in terms of social utility and commercial success (Guerrini, 2014; Reitzig, 2003). Despite different measures to determine the patent quality have been proposed, few studies have discussed the impacts of patent quality on the IS from a systematic perspective; the issue addressed by this paper. The main research question of this paper is: How do quality and value patent measures promote the development of IS for the diffusion of renewable energy technologies?

Currently, society faces grand societal challenges associated with the depletion of natural resources, involving the transition to clean technologies. One of the frameworks from innovation studies that have the potential to contribute to the understanding of sustainable technological change is the IS approach (Hekkert \& Negro, 2009). As technological change can be an essential driver of patent applications, given that it is one of the outputs of this process, it also can be used as a measure to understand the diffusion of climate-friendly technologies (Hall \& Helmers, 2013). Thus, this paper aims to contribute to this issue through a systemic intervention. In the case of the renewable energy sector, this intervention shows the impacts of patent quality.

Although patents play a prominent role in the IS, eventually low-quality patents may lead to "innovation system failure"; for instance, delays that affect the diffusion and use of a particular technology (Negro et al., 2012). Thus, a dynamic behaviour hypothesis in terms of the Causal Loop Diagram (CLD) can explain the effects of the delays on the IS. The dynamic behaviour hypothesis is a conceptual model that seeks to define the critical feedback loops that drive the system's behaviour (Bala et al., 2017; Sterman, 2000). In this paper, the dynamic behaviour hypothesis was designed to explain how patent quality contributes to the renewable energy innovation system.

Previous studies have shown the importance of the process of technology transfer as an essential aspect for the development of the renewable energy system (Herrera, Dyner, et al., 2019; Jimenez et al., 2016; Reichardt et al., 2017). However, a more detailed understanding of the innovation policy intervention, in terms of the patent indicators on the technology transfer process, is required. The paper addresses this gap in the literature by examining the role of the patent quality indicators for innovation systems.

The remainder of the paper is organised as follows: Section 2 introduces the methodology adopted to address the proposed question. Section 3 discusses the critical measurement of patent quality from a literature review, and exhibits a systemic intervention. In this section, a dynamic behaviour hypothesis shows the influence of patent quality on the IS and its economic implications. Finally, the paper presents the conclusions and future research directions. 


\section{Research method}

Figure 1 shows a brief representation of the research method carried out in this paper. The selected method comprises five steps: First, from the literature review, the co-occurrence of keywords was analysed and clustered. Second, a map was developed, defining documents published and citations received by sources (i.e. journals). Third, a discussion concerning quality patent indicators is carried out. Fourth, a dynamic behaviour hypothesis through a Causal Loop Diagram (CLD) is proposed for analysing the influence of patent quality on the renewable energy innovation system. Fifth, a chart is projected to identify essential drivers of patent quality that stimulates the innovation system.

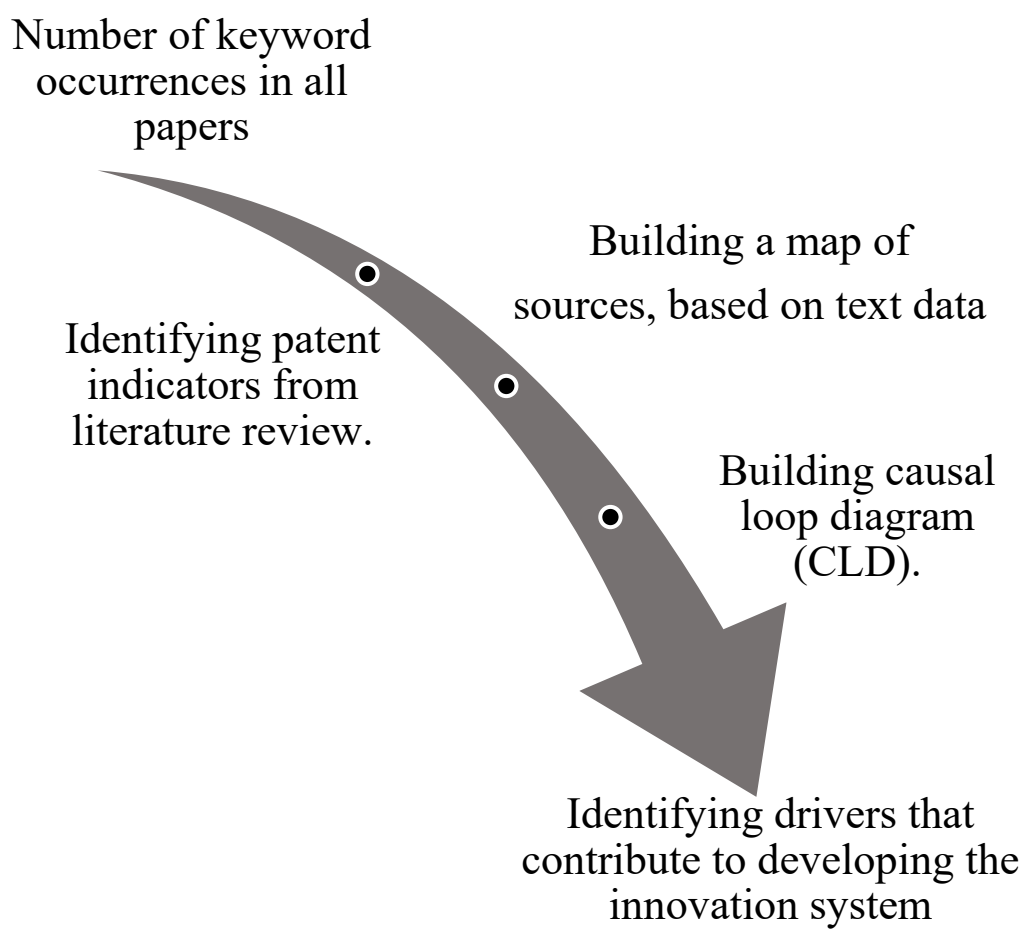

Figure 1. Flow diagram of the research method.

This paper conducted a systematic review that shows the patent quality indicators reported in the literature. The systematic search includes two databases - Web of Science and Scopus -, for published papers between 2011 and 2020. In both databases, the search was "patent indicators" or "measuring patents" or "patent value indicator" in the title, abstract and keywords (i.e. Scopus: TITLE-ABS-KEY("patent indicators" OR "measuring patents" OR "patent value indicator")), and in Web of Science: (TS=("patent indicators") OR $\mathrm{TS}=$ ("measuring patents") OR TS=("patent value indicator")). On the literature, "patent quality" and "patent value", some times are used as similar concepts to describe that a patent can have several characteristics related to the social and private usefulness of the document, and its related invention (Abbas et al., 2014; Mann, 2008).

After this process, the following step was to refine our search, keeping the relevant papers - Scopus (197 papers) and Web of Science (87 papers) - including discussions about patent quality indicators. Although our search was limited to journal articles, a few working papers and conference papers relevant were also included. 
¿Cómo la calidad de las patentes contribuye a revitalizar el sistema de innovación?, Evidencia desde el sector de energías renovables

Besides, the references of the papers were verified to identify other documents that our search may have not identified. Note that the materials found by the two databases were combined to remove duplicates.

Based on the systematic review, the paper shows a network of keywords that indicates the number of documents in which a word occurs at least once. The number of occurrences of a keyword was used to determine the relationship of words with the research issue in the entire documents. Subsequently, a source map was elaborated to analyze the number of papers and normalize their citations.

The normalized citation of a paper is calculated as the number of citations divided by the average number of citations of all papers in the same year (van Eck \& Waltman, 2020).

Abstract and titles of the papers were screened independently to identify patent indicators used by literature. Then, the full papers were screened to compare their results and discuss differences between the used indicators.

Additional to screening all the papers, a CLD was elaborated to understand the relationship between the patent quality indicator and the IS. A CLD can be defined as a simple representation used to describe and analyse the dynamic structure of a complex system (Bala et al., 2017; Mollona, 2008; Rahmandad et al., 2009; Sterman, 1989).

\section{Results and discussion}

This section presents the results in two parts: i) the systematic literature review developed (i.e., the first three steps) in subsection 3.1, and ii) the systemic intervention developed to represent the case study in subsection 3.2.

\subsection{Identifying measurement scales for patent quality from the literature review}

\section{Number of occurrences of a keyword}

A map was created based on bibliographic data files (i.e., Scopus and Web of Science) for exploring and visualising the keyword network (van Eck \& Waltman, 2020). Figure 2 shows this network visualisation, which represents the number of occurrences of a keyword in all the papers. The color of the keyword is determined by the cluster to which the item belongs.

The distance between two keywords determines a cluster, and denotes their relation in terms of neighbourhood (e.g., "patent indicators" and "patent analysis"). Likewise, the size of the circle indicates the number of occurrences of a keyword in entire papers. The results show twenty-three keywords identified into four clusters. The higher number of occurrences identified in author keywords, are: 29 occurrences of "patent indicators" in the first cluster; 20 occurrences of "patent analysis" in the first cluster; 20 occurrences of "patent" in the second cluster.

Other network attributes that show these results are total link strength. The total link strength attribute indicates the number of links of a keyword to other keywords (van Eck \& Waltman, 2020).

The higher number of links strength identified into four clusters are 14 links by "patent indicators", 13 links by "patent" and 10 links by "patent analysis". These results show that the patent indicator term in several reviewed papers is mainly associated with innovation and technology. 


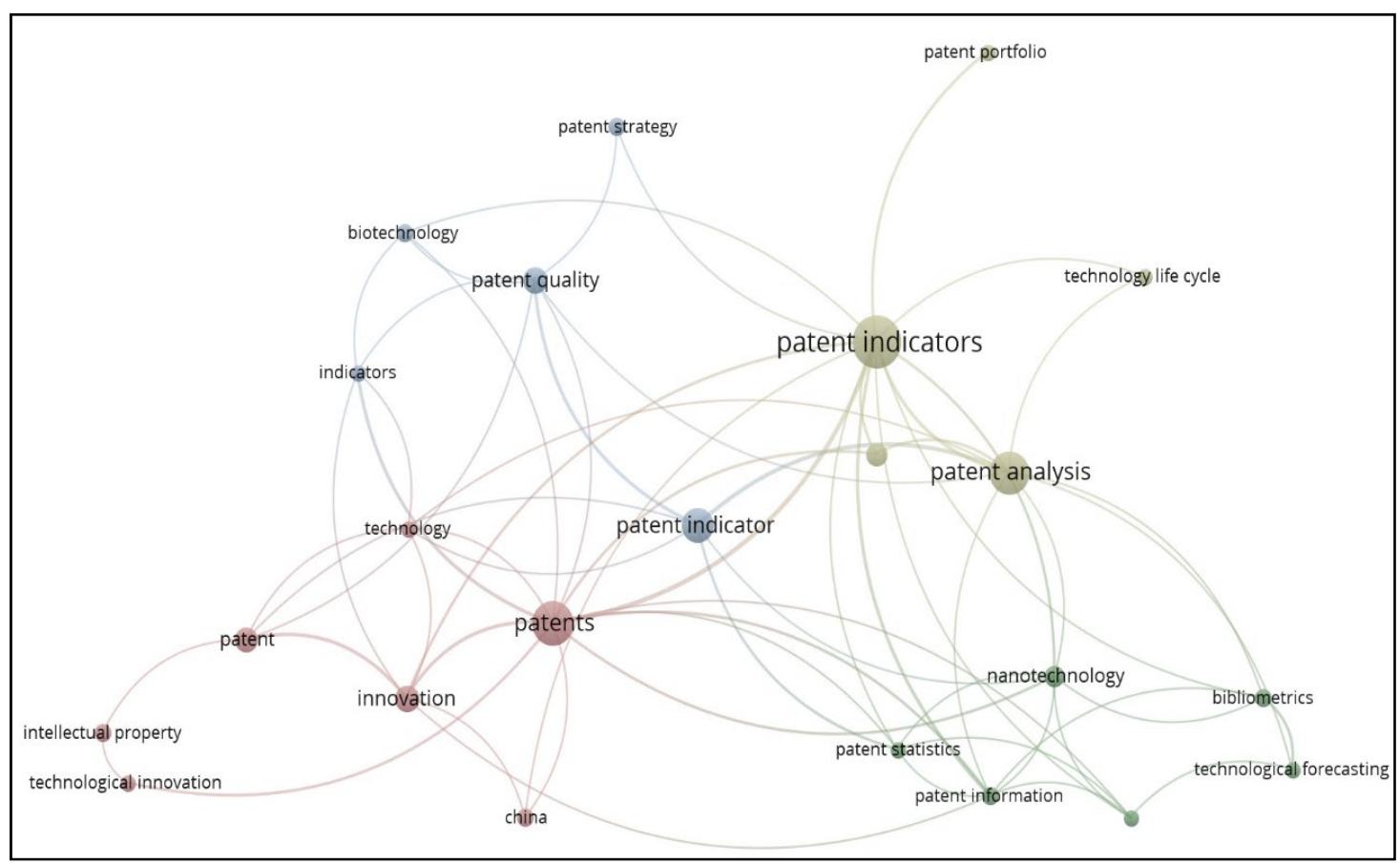

Figure 2. Number of occurrences of a keyword in all the documents (papers).

\section{Source Map (papers)}

The bibliographic data files were used to identify and built a network of sources and citations provided by literature. Figure 3 shows a map based on text data, in terms of papers published by journals and the number of citations received by those journals. On the one hand, the results show that the more prestigious journals in the patent indicator issue are: "Scientometrics" (9 papers), "Technological Forecasting and Social Change" (6 papers), "Research Policy" (5 papers) and "World Patent Information" (5 papers).
Moreover, the map identifies higher link strength - bibliographic coupling links - between "Scientometrics" and "World Patent Information", as illustrated in Figure 2(a). On the other hand, the higher normalized number of citations by journals is 23.56 citations ("Technological Forecasting and Social Change"), 7.46 citations ("Research Policy"), 5.51 citations ("Scientometrics") and 5.31 citations ("World Patent Information"), as illustrated in Figure 2(b). Note that the normalization corrects the fact that older papers have had more time to receive citations than more recent papers (van Eck \& Waltman, 2020). 


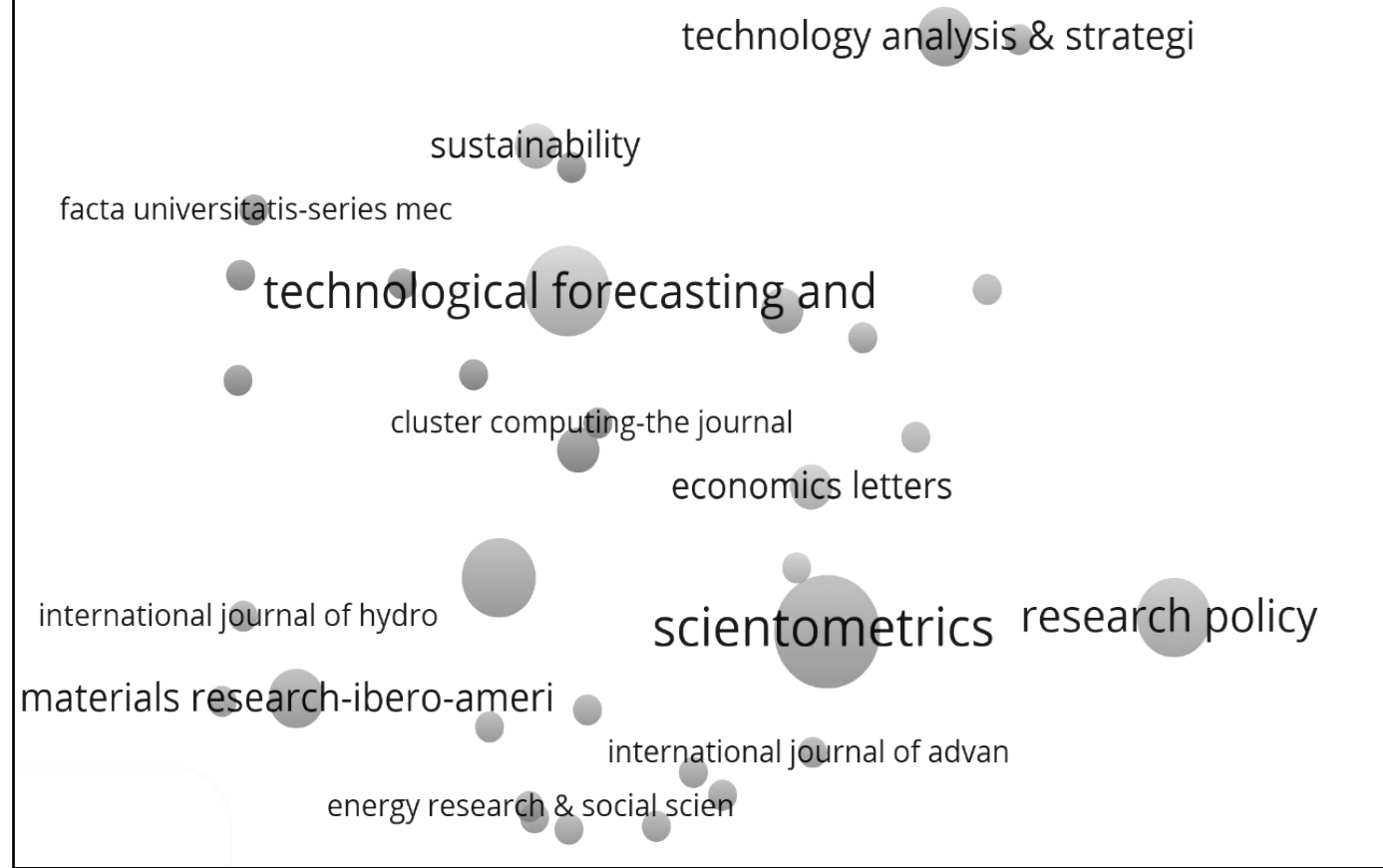

a) Number of documents published by sources (i.e. journal)

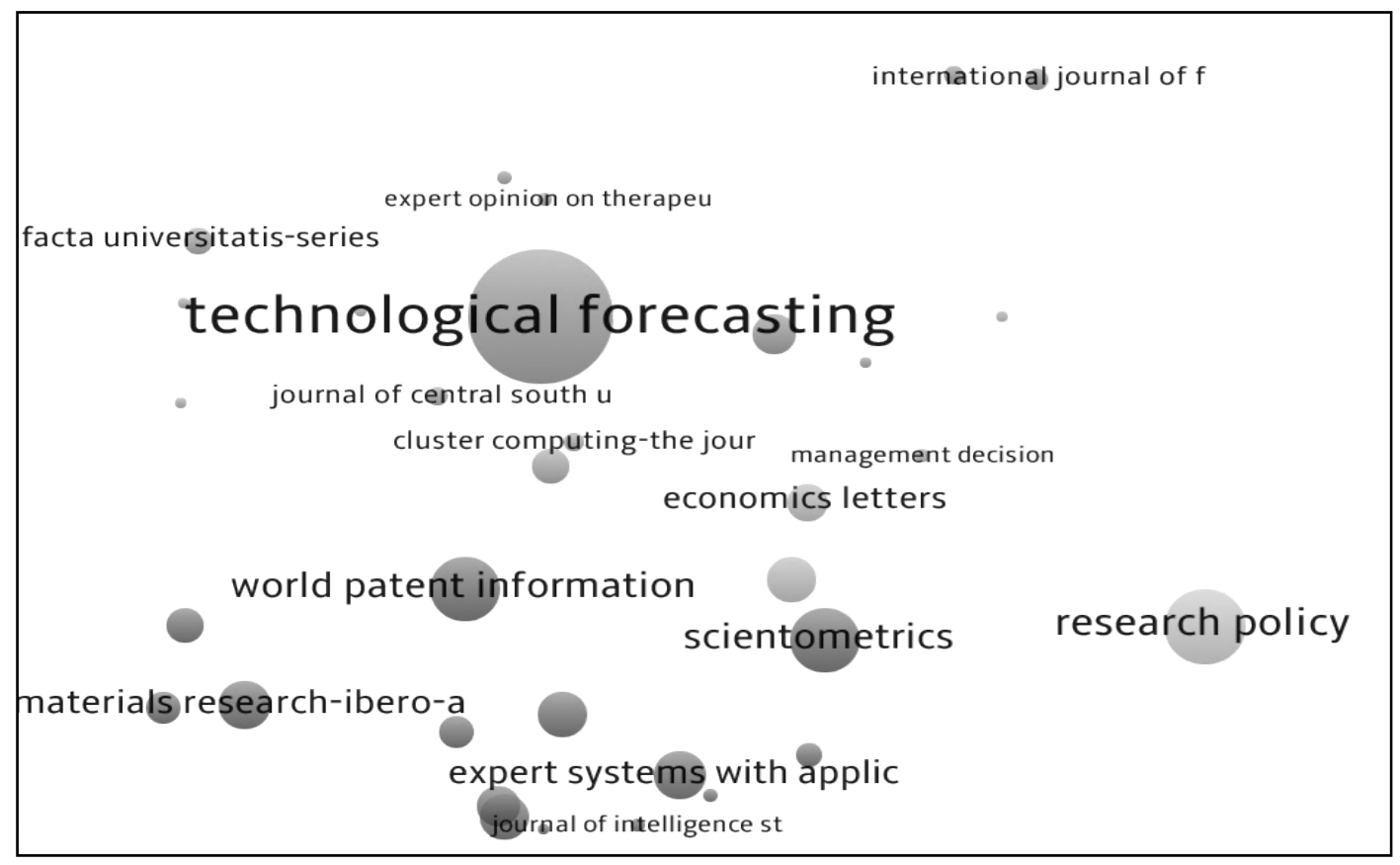

b) Normalized number of citations received by a source (i.e. journal)

Figure 3. Source Map based on text data provided by the systematic review. 
Identifying patent indicators

Researchers have created countless patent quality indicators to determine the potential impact of a given invention (Kapoor et al., 2015). Despite the existence of different patents quality indicators, citation-based indicators are the most used by researchers (Aristodemou \& Tietze, 2018; Chang et al., 2018; Kapoor et al., 2015). Citation-based indicators allow to identify the links between patents and helps to evaluate the originality and relevance of the innovation (Chang et al., 2018). Moreover, patent indicators provide information about the social utility and commercial success of the innovation process (Harrigan et al., 2017).

Citation-based indicators can be classified into two categories: i) the backward citations defined as the references made to previous patents, and ii) the forward citations determined by the references received from future patents. Backward citations are used to measure the knowledge transfer related with the invention (Hall et al., 2005; Harhoff et al., 1999; Reitzig, 2003), while forward citations are used to measure the technological impact of innovation (Kapoor et al., 2015; van Zeebroeck, 2011; Verhoeven et al., 2016). Although citation information has provided useful information on the value of patents, backward citations, as an indicator of information have been more controversial (Nagaoka et al., 2010).

According to the different patent indicators, Trajtenberg (1990), introduced forward citations as patent value indicators which have been used in numerous studies (Harhoff \& Reitzig, 2004; Lanjouw \& Schankerman, 2002). Subsequently, Hall \& Jaffe (2001), used normalized citation counts by technology and priority years of the patent. A constraint in this method is that it does not investigate how the patent quality progresses over time (Boeing \& Mueller, 2019). Reitzig (2004), applied value indicators to estimate the value of patents - classifying the indicators into first, second and third generations. The first generation includes forward and backward citation data and patent family size. The International Patent Classification (IPC), is used in the second generation; lastly, the third generation incorporates claims of the patent application. Lanjouw \& Schankerman (2004), proposed a patent value indicator to assess $R \& D$ performance that includes several patent indicators (e.g., patent family size). The results of the study of Lanjouw \& Schankerman (2004), show that companies with more selfcitations are capable to obtaining returns from earlier investment in R\&D and demonstrate the presence of suitable innovation processes. This study concludes that the use of multiple indicators reduces variation between 20 and $73 \%$ in the measure of patent quality.

Other studies extended the quality indicators, for instance, Beaudry \& Schiffauerova (2011), estimate the impacts of collaboration and network indicators on patent quality - including the number of claims (the set of requests that the applicant is claiming to the patent authority to be protected), of the patent application- as a central variable of the study. Saint-Georges, Pottelsberghe \& Potterie (2011), incorporate a novel model that includes the measure of patent quality to analyze the implications of intellectual property rights. Ernst \& Omland (2011) developed a novel benchmarking methodology for assessing a firm's patent portfolio vis-à-vis its competitors. The study concludes that the developed method becomes an indicator of innovativeness and sustainable competitive advantage in many industries. Moreover, some studies show how patent quality is associated with individual features of inventors in terms of individual characteristics (e.g., age, gender and level of education) which influences on the creation of the network (Pinto et al., 2019; Schettino et al., 2013).

A previous literature review identified nine forward citation-based measures (Aristodemou \& Tietze, 2018). The measure is divided into two categories: i) the patent level (citation index, influence, forward citation, generality), and ii) the patent portfolio level (relative patent position, technology strength, current impact index, hindrance index). However, the study addressed 
¿Cómo la calidad de las patentes contribuye a revitalizar el sistema de innovación?, Evidencia desde el sector de energías renovables

by Aristodemou \& Tietze (2018), only provides a quick access point to the literature of forwarding citation-based measure.

\subsection{Systemic intervention}

On one hand, the paper presents a case study of renewable energy technologies for three reasons. First, R\&D activities and patent applications in the renewable energy sector have significantly increased. Second, patent management activities such as valuation are especially crucial for renewable energy diffusion, particularly in Latin-America (Leusin et al., 2018). Finally, climate change brings challenges and opportunities for renewable energy technologies which promote R\&D activities, fostering the social use of the patents (Miyamoto \& Takeuchi, 2019). On the other hand, given that patents are innovation process output-indicators, literature reviews reinforce the fact that there must be a relationship between the quality of those outputs, and the quality of the complete innovation system; therefore, a link between the known indicators of wellfunctioning innovation systems and patents can be backed.

Table 1 shows the functions of an innovation system addressed by previous studies on the renewable energy diffusion (Kebede \& Mitsufuji, 2017; Negro et al., 2012; Suurs, 2009). This paper adopts the functions approach to draw the relationship between the patent quality and the IS. As Hekkert, et al. (2007) claims, a systemic perspective based on innovation functions allows a mapping method of innovation determinants.

Table 1. Functions of a technological innovation system (TIS) (based on Hekkert et al., 2007; Hekkert \& Negro, 2009; Miremadi et al., 2018; Suurs, 2009).

TIS Functions

Knowledge development

Knowledge diffusion

Guidance of the research

Entrepreneurial activities

Market formation

Resource mobilization

Creation of legitimacy

\section{Description}

This function encompasses the activities for generating knowledge within the innovation system.

This function has the purpose of transfering knowledge through the interaction between actors (i.e., fostering networks).

Covers the activities within the IS that affect the specific applications of the technology.

The role of the entrepreneur is to revitalize the potential of new knowledge, networks and markets into strategies to generate advantages for the business.

This function includes the formation of volatile niche markets for specific applications of the technology.

Comprises the activities associated with the allocation of resources as an input function to the innovation system.

This function comprises the activities that guarantee the acceptance of the new technology.

We allocated patent indicators, based on the literature review, to seven innovation functions to enable assessment of their strength through a CLD, as illustrated in Figure 4. The CLD shows how green patent quality influences in renewable energy diffusion and R\&D funding and activities, creating a balanced loop (B1). The investment of new renewable capacity generates incentives to patent, influencing innovation policy reforms as well as new investments in capacity, reinforcing loops R1 and R2. The reinforcing of loop (R3) represents the influence of $R \& D$ investment to promote green patents for the electricity sector. Fostering $R \& D$ activities is required to stimulate changes to the innovation policy, adopting incentives to build renewable energy capacity (reinforcing of loop R4). 


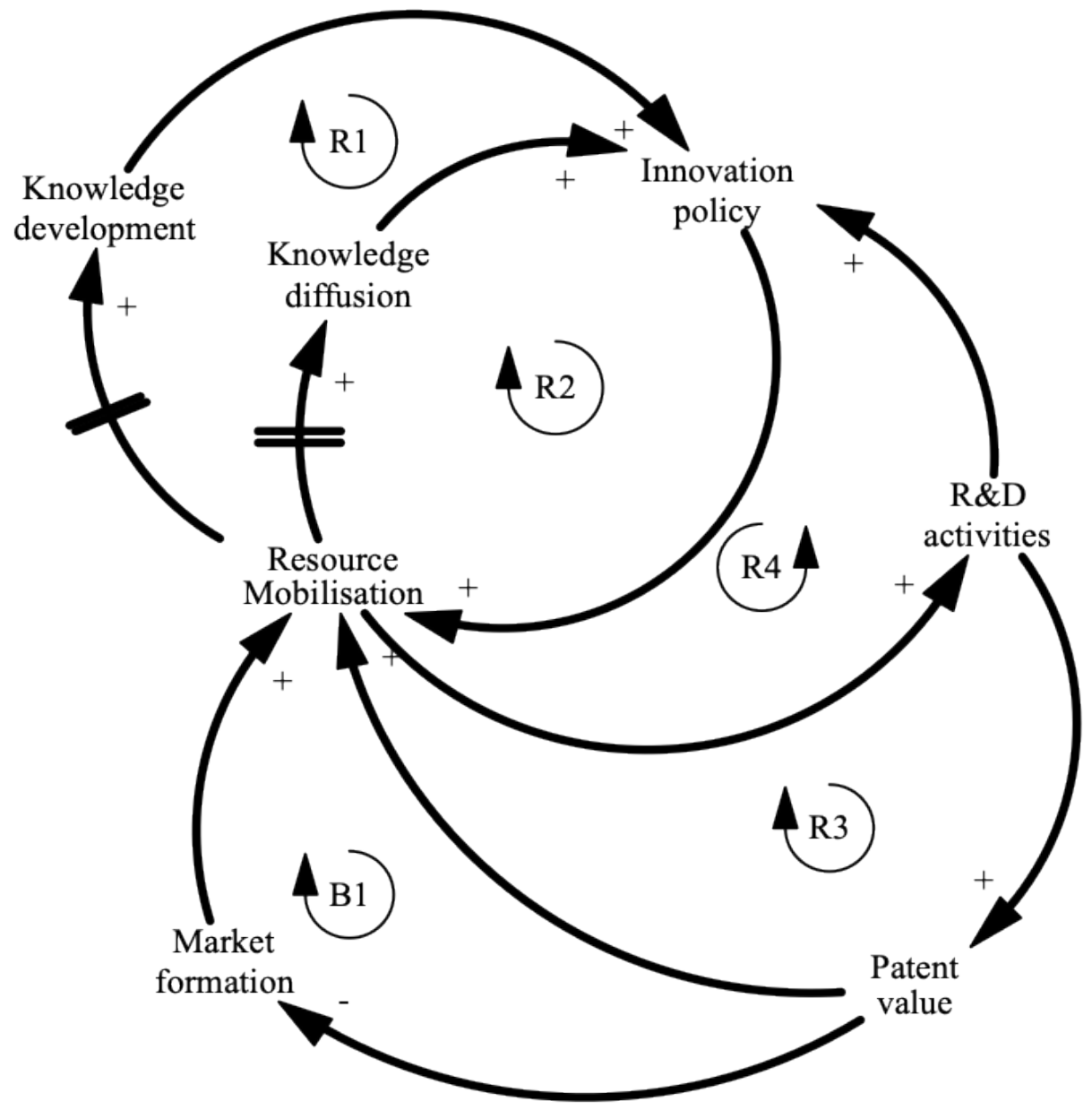

Figure 4. CLD developed to identify the main interactions between patent indicators and IS functions for the case study.

From the CLD, Table 2 shows a combination of patent indicators and indicators for assessing IS functions proposed by Miremadi et al. (2018). The construction of this set of functions

$$
\begin{aligned}
& \operatorname{EfPI}(s)=\frac{1-S}{1+\exp 1,25}+S \\
& \operatorname{EfPI}(s)=\left\{\begin{array}{c}
0.22, \text { if } S=0 \\
0.61, \text { if } 0.5>S \geq 0 \\
1, \text { if } 1 \geq S>0.6
\end{array}\right.
\end{aligned}
$$
and their links to patent indicators are based on a membership function, as illustrated in Equation (1). The Equation calculates the strength of the effects of the patent indicator (S) - EfPI(s) - on the indicator of IS functions. Note that values of $0.22,0.61$ and 1 only represent membership or non-membership of the patent indicator in the case of the renewable energy sector. 
¿Cómo la calidad de las patentes contribuye a revitalizar el sistema de innovación?, Evidencia desde el sector de energías renovables

Table 2. Summary of patent indicators and their links to indicators used to measure IS functions (based on Lee et al., 2018; Miremadi et al., 2018).

\begin{tabular}{cccccccc}
\hline & \multicolumn{6}{c}{ Innovation system functions } \\
\cline { 2 - 7 } $\begin{array}{c}\text { Patent } \\
\text { indicators }\end{array}$ & $\begin{array}{c}\text { Knowledge } \\
\text { development }\end{array}$ & $\begin{array}{c}\text { Knowledge } \\
\text { diffusion }\end{array}$ & $\begin{array}{c}\text { Guidance } \\
\text { of the } \\
\text { search }\end{array}$ & $\begin{array}{c}\text { Entrepreneurial } \\
\text { activities }\end{array}$ & $\begin{array}{c}\text { Market } \\
\text { formation }\end{array}$ & $\begin{array}{c}\text { Resource } \\
\text { mobilization }\end{array}$ & $\begin{array}{c}\text { Creation of } \\
\text { legitimacy }\end{array}$ \\
\hline FC & SPP (1) & WC (1) & & & & \\
BC & SPP (1) & KEN (1) & & EDA (1) & & \\
TO & & KEN (1) & SDT (1) & & & \\
TCT & & & SDT (1) & EA (1) & NM (1) & & TAS (1) \\
TS & & KEO (1) & & & NM (1) & TAS (1) \\
CS & RF (1) & NSI (1) & & & FDI (1) & \\
C & RF (1) & NSI (1) & & & FR (1) & \\
\hline I & & & & & & \\
\hline
\end{tabular}

Type of patent indicators (S)

FC: forward citation

BC: backward citation

TO: technological originality

TCT: technology cycle time

TS: technological scope

CS: commercial scope

C: collaboration

I: inventors

\section{Indicators used to measure IS functions}

SPP: scientific publication and patenting

NSI: network size and intensity

RF: number of R\&D projects

KEN: knowledge exchange in networks

WC: workshops and conferences

KEO: knowledge exchange between organizations

SDT: routing development towards specific technological alternatives
NM: number of niche markets

TAS: technical assessment studies

FR: financial resources

EDA: experimentation and demonstration activities

\section{EA: export activities}

FDI: foreign direct investment

$\mathrm{RGI}$ : rise and growth of interest groups

Improved diffusion of innovations for the renewable energy sector, requires a strategic initiative that contributes to stimulating the adoption of clean technologies such as wind and solar power (Herrera, Cosenz, et al., 2019). The systemic intervention suggests a set of alternatives in the renewable energy sector for revitalizing the IS, including market formation, creation of legitima$c y$, and identifying relevant sectors.

Fostered social utility and commercial success market formation

Previous studies show how the "wicked social problems" hamper the diffusion of renewable energy technologies because social utility and impacts of the new inventions are not considered (Brannstrom et al., 2017; Gorayeb et al., 2018; 
Negro et al., 2012). First, this may require the development of an innovation policy focused on inventions, which reflect the social utility of the local economy. As argued by Kitson (2019), a similar interventions policy may lead to very different impacts in other places. Second, building networks facilitate the market formation and commercial success, to improve the diffusion of clean technologies appropriate for the local economy. The networks allow managing value chains that stretch globally functioning as a structural coupling element (Bergek et al., 2015).

\section{Creation of legitimacy and political context}

The R\&D activities to develop new inventions and patent applications become a crucial aspect for IS-based policy-making (see, reinforcing loop R2 and R4). As Bergek et al. (2015) claims, the availability of public financial resources for research and development, contributes to increased societal legitimacy of the technological field that positively impacts on the entry of new actors - investors, entrepreneurs and local governments - who bring resources to the IS. In this sense, the alignment between institutions and entrepreneurs could improve the innovation policy design to gain access to the necessary resources for the development of new technologies.

\section{Identifying relevant sectors for patent applications}

The resource mobilization function comprises the activities associated with the allocation of resources as an input function to the innovation system - mainly contributing to serving the sector overall. Sectors rely on a broad set of technologies in various stages of maturity and consequently, on different IS (Aguirre-Bastos \& Weber, 2018; Bergek et al., 2015), which involve identifying strategic resources to revitalize innovation activities. Thus, the identification of relevant sectors for the patent applications contributes to improving the allocation of resources both at public institutions and private sectors.

\section{Conclusions}

From the literature review, a critical difficulty identified is that patent quality, in terms of useful social results, is generally not well-defined within the IS. The innovation activity is highly concentrated in two innovation functions - knowledge development and diffusion - ignoring at times, market formation and creation of legitimacy. Previous studies argue the difficulty generated by this issue in the diffusion of renewable energy (Negro et al., 2012). In this sense, this paper combines patent quality indicators with the IS functions for identifying drivers to promote renewable energy technologies.

The systemic interaction shows that patent value stimulates the dynamic of the IS particularly new investment for the R\&D activities and promotes the sustainability transition in the renewable energy sector, especially because, according to literature, there is a connection between technical quality, economical and social value. The paper ends with a reflection of the strategies that may revitalise the IS supported by $R \& D$ activities which could increase patent applications.

Future works will include a formal simulation structure based on the CLD, known as a stockand-flow diagram, for identifying essential drivers that stimulate the innovation system in the long-term. To further investigate the role of a patent indicator in Latin-America, innovative frameworks to measure the innovation activity based on an aggregated indicator for each country should be developed.

\section{Acknowledgements}

The paper has been written within the framework of the project: Generación de un índice de calidad de patentes para Latina-América. The authors acknowledge the financial support provided by the Universidad Militar Nueva Granada (INV-ECO-2697). 
¿Cómo la calidad de las patentes contribuye a revitalizar el sistema de innovación?, Evidencia desde el sector de energías renovables

\section{References}

Abbas, A., Zhang, L., \& Khan, S. U. (2014). A literature review on the state-of-the-art in patent analysis. World Patent Information, 37, 3-13. https://doi. org/10.1016/j.wpi.2013.12.006

Aguirre-Bastos, C., \& Weber, M. K. (2018). Foresight for shaping national innovation systems in developing economies. Technological Forecasting and Social Change, 128 (3), 186-196. https://doi. org/10.1016/j.techfore.2017.11.025

Aristodemou, L., \& Tietze, F. (2018). Citations as a measure of technological impact: $A$ review of forward citation-based measures. World Patent Information, 53 (6), 39-44. https://doi. org/10.1016/j.wpi.2018.05.001

Bala, B. K., Arshad, F. M., \& Noh, K. M. (2017). System Dynamics: Modelling and Simulation. In Springer. https://doi.org/10.1007/SpringerReference_7284

Barroso, W., Quoniam, L., \& Pacheco, E. (2009). Patents as technological information in Latin America. World Patent Information, 31 (3), 207-215. https://doi.org/10.1016/j.wpi.2008.11.006

Beaudry, C., \& Schiffauerova, A. (2011). Impacts of collaboration and network indicators on patent quality: The case of Canadian nanotechnology innovation. European Management Journal, 29 (5), 362-376. https://doi.org/10.1016/j. emj.2011.03.001

Bergek, A., Hekkert, M., Jacobsson, S., Markard, J., Sandén, B., \& Truffer, B. (2015). Technological innovation systems in contexts: Conceptualizing contextual structures and interaction dynamics. Environmental Innovation and Societal Transitions, 16, 51-64. https://doi.org/10.1016/j. eist.2015.07.003

Boeing, P., \& Mueller, E. (2016). Measuring patent quality in cross-country comparison. Economics Letters, 149, 145-147. https://doi.org/10.1016/j. econlet.2016.10.039

Boeing, P., \& Mueller, E. (2019). Measuring China's patent quality: Development and validation of ISR indices. China Economic Review, 57(July
2018), 101331. https://doi.org/10.1016/j.chieco.2019.101331

Brannstrom, C., Gorayeb, A., de Sousa Mendes, J., Loureiro, C., Meireles, A. J. de A., Silva, E. V. da, Freitas, A. L. R. de, \& Oliveira, R. F. de. (2017). Is Brazilian wind power development sustainable? Insights from a review of conflicts in Ceará state. Renewable and Sustainable Energy Reviews, 67 (1), 62-71. https://doi.org/10.1016/j. rser.2016.08.047

Chang, S. H., Chang, H. Y., \& Fan, C. Y. (2018). Structural model of patent quality applied to various countries. International Journal of Innovation Science, 10 (3), 371-384. https://doi.org/10.1108/ IJIS-05-2017-0036

Ernst, H. (2003). Patent information for strategic technology management. World Patent Information, 25 (3), 233-242. https://doi.org/10.1016/ S0172-2190(03)00077-2

Ernst, H., \& Omland, N. (2011). The Patent Asset Index - A new approach to benchmark patent portfolios. World Patent Information, 33 (1), 34-41. https://doi.org/10.1016/j.wpi.2010.08.008

Gorayeb, A., Brannstrom, C., de Andrade Meireles, A. J., \& de Sousa Mendes, J. (2018). Wind power gone bad: Critiquing wind power planning processes in northeastern Brazil. Energy Research and Social Science, 40 (6), 82-88. https:// doi.org/10.1016/j.erss.2017.11.027

Guerrini, C. J. (2014). Defining Patent Quality. Fordham Law Review, 82 (6), 3092-3141.

Hall, B. H., \& Helmers, C. (2013). Innovation and diffusion of clean/green technology: Can patent commons help?. Journal of Environmental Economics and Management, 66 (1), 33-51. https:// doi.org/10.1016/j.jeem.2012.12.008

Hall, B. H., \& Jaffe, A. B. (2001). The nber patent citations data file: Lessons, insights and metholodigal tools.

Hall, B. H., Jaffe, A., \& Trajtenberg, M. (2005). Market value and patent citations. RAND Journal of Economics, 36 (1), 16-38. 
Harhoff, D., Narin, F., Scherer, F. M., \& Vopel, K. (1999). Citation frequency and the value of patented inventions. Review of Economics and Statistics, 81 (3), 511-515. https://doi. org/10.1162/003465399558265

Harhoff, D., \& Reitzig, M. (2004). Determinants of opposition against EPO patent grants - The case of biotechnology and pharmaceuticals. International Journal of Industrial Organization, 22 (4), 443-480. https://doi.org/10.1016/j.ijindorg.2004.01.001

Harrigan, K. R., Di Guardo, M. C., Marku, E., \& Velez, B. N. (2017). Using a distance measure to operationalise patent originality. Technology Analysis and Strategic Management, 29 (9), 988-1001. https://doi.org/10.1080/09537325.20 16.1260106

Hekkert, M., \& Negro, S. (2009). Functions of innovation systems as a framework to understand sustainable technological change: Empirical evidence for earlier claims. Technological Forecasting and Social Change, 76 (4), 584-594. https://doi. org/10.1016/j.techfore.2008.04.013

Hekkert, M., Suurs, R., Negro, S., Kuhlmann, S., \& Smits, R. (2007). Functions of innovation systems: A new approach for analysing technological change. Technological Forecasting and Social Change, 74 (4), 413-432. https://doi.org/10.1016/j. techfore.2006.03.002

Herrera, M. M., Cosenz, F., \& Dyner, I. (2019). How to support energy policy coordination? Findings from the Brazilian wind industry. The Electricity Journal, 32 (8), 106636. https://doi.org/10.1016/j. tej.2019.106636

Herrera, M. M., Dyner, I., \& Cosenz, F. (2019). Assessing the effect of transmission constraints on wind power expansion in northeast Brazil. Utilities Policy, 59, 100924. https://doi.org/10.1016/j. jup.2019.05.010

Jimenez, M., Franco, C. J., \& Dyner, I. (2016). Diffusion of renewable energy technologies: The need for policy in Colombia. Energy, 111, 818-829. https://doi.org/10.1016/j.energy.2016.06.051
Kapoor, R., Karvonen, M., Ranaei, S., \& Kässi, T. (2015). Patent portfolios of European wind industry: New insights using citation categories. World Patent Information, 41, 4-10. https://doi. org/10.1016/j.wpi.2015.02.002

Kebede, K. Y., \& Mitsufuji, T. (2017). Technological innovation system building for diffusion of renewable energy technology: A case of solar PV systems in Ethiopia. Technological Forecasting and Social Change, 114, 242-253. https://doi. org/10.1016/j.techfore.2016.08.018

Kitson, M. (2019). Innovation policy and place: A critical assessment. Cambridge Journal of Regions, Economy and Society, 12 (2), 293-315. https://doi. org/10.1093/cjres/rsz007

Lanjouw, J. O., \& Schankerman, M. (2002). Research productivity and patent quality: measurement with multiple indicators. The Economic Journal, 114 (495), 441-465.

Lanjouw, J. O., \& Schankerman, M. (2004). Patent quality and research productivity: Measuring innovation with multiple indicators. Economic Journal, 114 (495), 441-465. https://doi. org/10.1111/j.1468-0297.2004.00216.x

Lee, C., Kwon, O., Kim, M., \& Kwon, D. (2018). Early identification of emerging technologies: A machine learning approach using multiple patent indicators. Technological Forecasting and Social Change, 127 (2), 291-303. https://doi. org/10.1016/j.techfore.2017.10.002

Leusin, M. E., Vaz, C. R., \& Uriona Maldonado, M. (2018). Mapeamento Tecnológico de Patentes em Energia Eólica no Brasil. Future Studies Research Journal: Trends and Strategies, 10 (2), 303-331. https://doi.org/10.24023/futurejournal/2175-5825/2018.v10i2.313

Lu, B. (2013). Expedited patent examination for green inventions: Developing countries' policy choices. Energy Policy, 61, 1529-1538. https://doi. org/10.1016/j.enpol.2013.06.028

Mann, R. (2008). A New Look at Patent Quality. American Law \& Economics Association Papers, 9 (41), 1-8. 
¿Cómo la calidad de las patentes contribuye a revitalizar el sistema de innovación?, Evidencia desde el sector de energías renovables

Miremadi, I., Saboohi, Y., \& Jacobsson, S. (2018). Assessing the performance of energy innovation systems: Towards an established set of indicators. Energy Research and Social Science, 40 (6), 159-176. https://doi.org/10.1016/j.erss.2018.01.002

Miyamoto, M., \& Takeuchi, K. (2019). Climate agreement and technology diffusion: Impact of the Kyoto Protocol on international patent applications for renewable energy technologies. Energy Policy, 129 (6), 1331-1338. https://doi. org/10.1016/j.enpol.2019.02.053

Mollona, E. (2008). J. Morecroft, Strategic Modelling and Business Dynamics. A Feedback Systems Approach. Journal of Management \& Governance, 12, 213-217. https://doi.org/10.1007/s10997-0089050-0

Nagaoka, S., Motohashi, K., \& Goto, A. (2010). Chapter 25 - Patent Statistics as an Innovation Indicator. In B. H. Hall \& N. Rosenberg (Eds.), Handbook of the Economics of Innovation, 2 (2), 1083-1127). North-Holland. https://doi.org/ https://doi.org/10.1016/S0169-7218(10)02009-5

Negro, S. O., Alkemade, F., \& Hekkert, M. P. (2012). Why does renewable energy diffuse so slowly? A review of innovation system problems. Renewable and Sustainable Energy Reviews, 16 (6), 38363846. https://doi.org/10.1016/j.rser.2012.03.043

Pinto, P. E., Vallone, A., \& Honores, G. (2019). The structure of collaboration networks: Findings from three decades of co-invention patents in Chile. Journal of Informetrics, 13 (4), 100984. https://doi.org/10.1016/j.joi.2019.100984

Rahmandad, H., Repenning, N., \& Sterman, J. (2009). Effects of feedback delays on learning. System Dynamics Review, 25(4), 309-338. https:// doi.org/10.1002/sdr.427

Reichardt, K., Rogge, K. S., \& Negro, S. O. (2017). Unpacking policy processes for addressing systemic problems in technological innovation systems: The case of offshore wind in Germany. Renewable and Sustainable Energy Reviews, 80 (1), 1217-1226. https://doi.org/10.1016/j. rser.2017.05.280
Reitzig, M. (2003). What determines patent value?. Research Policy, 32 (1), 13-26. https://doi. org/10.1016/S0048-7333(01)00193-7

Reitzig, M. (2004). Improving patent valuations for management purposes-validating new indicators by analyzing application rationales. Research Policy, 33 (6-7), 939-957. https://doi. org/10.1016/J.RESPOL.2004.02.004

Romano, A. A., Scandurra, G., Carfora, A., \& Fodor, M. (2017). Renewable investments: The impact of green policies in developing and developed countries. Renewable and Sustainable Energy Reviews, 68 (2), 738-747. https://doi.org/10.1016/j. rser.2016.10.024

Saint-Georges, M. De, Pottelsberghe, B. Van, \& Potterie, D. (2011). A quality index for patent systems. Research Policy, 42 (3), 704-719. https:// doi.org/10.1016/j.respol.2012.09.003

Schettino, F., Sterlacchini, A., \& Venturini, F. (2013). Inventive productivity and patent quality: Evidence from Italian inventors. Journal of Policy Modeling, 35 (6), 1043-1056. https://doi. org/10.1016/j.jpolmod.2013.02.008

Squicciarini, M., Dernis, H., \& Criscuolo, C. (2013). Measuring patent quality: indicators of technological and economic value. STI Workign Papers Series, 1-62.

Sterman, J. (2000). Business dynamics: Systems Thinking and Modeling for a Complex World. McGraw-Hill.

Sterman, J. (1989). Modeling Managerial Behavior: Misperceptions of Feedback in a Dynamic Decision Making Experiment. Management Science, 35 (3), 321-339. https://doi.org/10.1287/ mnsc.35.3.321

Suurs, R. A. A. (2009). Motors of sustainable innovation: Towards a theory on the dynamics of technological innovation systems. Nederlandse Organisatie voor Wetenschappelijk Onderzoek (NWO) (Issue February).

Trajtenberg, M. (1990). A Penny for Your Quotes : Patent Citations and the Value of Innovations. The RAND Journal of Economics, 21 (1), 172-187. 
Tseng, Y. H., Lin, C. J., \& Lin, Y. I. (2007). Text mining techniques for patent analysis. Information Processing and Management, 43 (5), 1216-1247. https://doi.org/10.1016/j.ipm.2006.11.011

van Eck, N. J., \& Waltman, L. (2020). Manual for VOSviewer version 1.6.15. Univeristeit Leiden (Issue April).

van Zeebroeck, N. (2011). The puzzle of patent value indicators. Economics of Innovation and New Technology, 20 (1), 33-62. https://doi. org/10.1080/10438590903038256

Verhoeven, D., Bakker, J., \& Veugelers, R. (2016). Measuring technological novelty with patentbased indicators. Research Policy, 45 (3), 707-723. https://doi.org/10.1016/j.respol.2015.11.010 